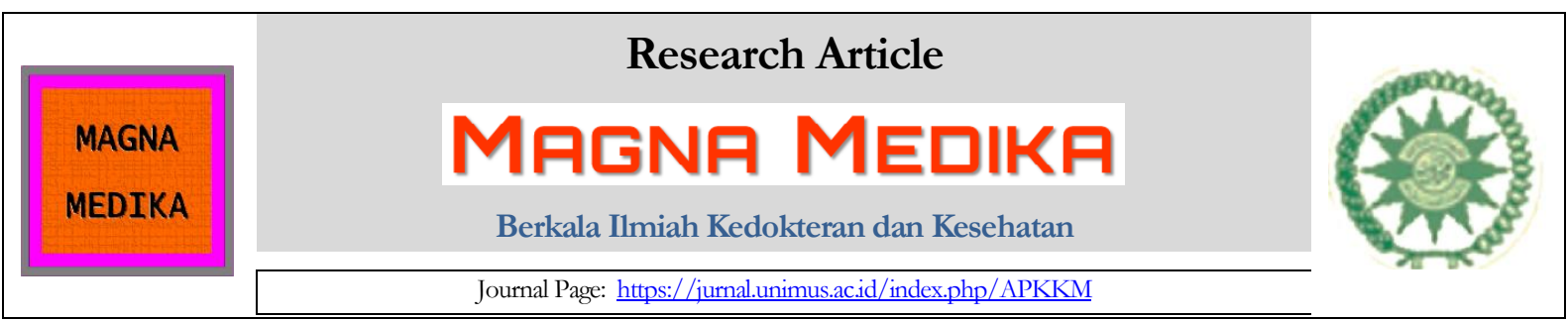

\title{
Anopheles Mosquito Species in Betung Bedarah, Tebo Regency, Jambi Province
}

\author{
Maas M Maloha ${ }^{1}$, Kanti Ratnaningrum ${ }^{2}$ \\ 1)Jambi Provincial Health Office, Indonesia, 2)Basic Clinical Science Department, Parasitology Sub-department, Faculty of Medicine, \\ Universitas Muhammadiyah Semarang, Indonesia
}

\begin{tabular}{l}
\multicolumn{1}{c}{ Article Info } \\
\hline Article history: \\
Received 28 January 2021 \\
Revised 30 January 2021 \\
Accepted 30 January 2021 \\
Available online 1 February 2021 \\
\hline
\end{tabular}

Keywords:

Mosquito; Malaria; Anopheles; Jambi

\section{Correspondence:}

kantiratna@unimus.ac.id

How to cite this article:

Maloha MM, Ratnaningrum K. Anopheles Mosquito Species in Betung Bedarah, Tebo Regency, Jambi Province. MAGNA

MEDIKA Berk Ilm Kedokt dan Kesehat. 2021;8(1):35-39

\begin{abstract}
Background: Indonesia is a tropical country which is a good breeding ground for mosquitoes. Mosquitoes are still one of arthropods that contribute to occurrence of infectious diseases, including malaria, which is a disease that is a health problem in Jambi Province.
\end{abstract}

Objective: To determine types of Anopheles mosquito spesies in Betung Bedarah Tebo, Jambi.

Methods: A discriptif study to identifed distribution of mosquitoes in Betung Bedarah, Tebo Regency used human landing collection and resting collection methods. Collection of mosquito samples used an aspirator and light trap. Analysis used tabulation.

Results: Of the 64 mosquitoes collected, 25\% were Anopheles mosquitoes which consisted of 43.7\% Anopheles barbirostris, 25\% Anopheles vagus, 18.7\% Anopheles aconitus, and 12.6\% Anopheles kochi.

Conclusion: Most of mosquito species collected at Betung Berdarah Tebo were Anopheles barbirostris. 


\section{INTRODUCTION}

Malaria is still one of health problems in Indonesia and Indonesia is a malaria holoendemic because malaria is found throughout the year. Malaria is a disease caused by Plasmodium parasite and transmitted through of Anopheles mosquito bite. ${ }^{1}$ Of the 424 Anopheles mosquitoes that have been identified morphologically, there are 70 species which are the main vectors of malaria in the world. Prevalent distribution of Anopheles mosquitoes in South Asia can be seen in Figure 1. There are 15 species of Anophels that contribute to malaria in Indonesia. ${ }^{2}$ Dominant Anopheles species found in Sumatra island include Anopheles sundaicus, Anopheles maculatus, Anopheles aconitus. ${ }^{1}$

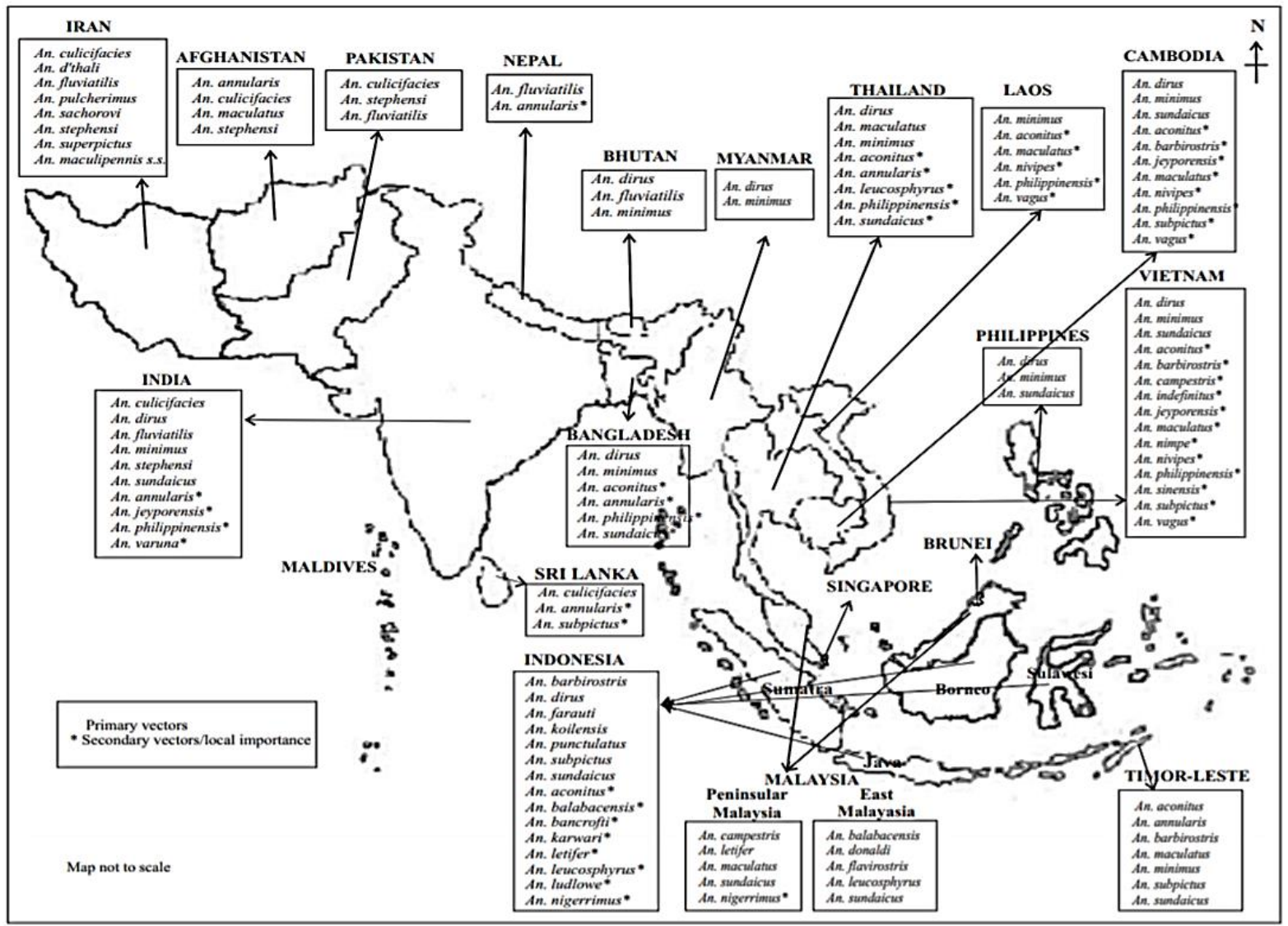

Figure 1: Malaria vectors prevalent in South Asia, South-East Asia and neighbouring countries ${ }^{2}$

Malaria is one of priority health problems for infectious diseases in Jambi Province, Sumatra island. Tebo Regency is one of regions in Jambi Province, with a malaria morbidity rate (Annual Parasite Inciddence/ API) of 0.172 per 1000 population and ranks second as the district with highest malaria disease. ${ }^{3}$ Previous research stated that Anopheles was largest mosquito distribution that contributed to human disease in the Betung Bedarah, Tebo Regency (25.00\%), followed by Culex $(17.19 \%)$, and Mansonia (14.06\%), and the other was Armigeres (43.75\%). Armigeres dominates mosquito finded in that study. ${ }^{4}$ There are several species found in Jambi Province area including Anopheles nigerrimus, ${ }^{5-8}$ Anopheles umbrosus, ${ }^{5,6}$ Anopheles subalbatus, ${ }^{5}$ Anopheles barbirostris, Anopheles vagus, Anopheles aconitus, Anopheles kochi, Anopheles umbrosus. ${ }^{6}$ Anopheles barbumbrosus, Anopheles letifer, Anopheles separatus, Anopheles sinensis. ${ }^{5,8}$ Anopheles tesselatus, dan Anopheles annularis. ${ }^{8}$ Several studies that have been conducted in Jambi Province have shown varying 
results regarding Anophles mosquito species, therefore researchers wanted to know distribution

\section{METHODS}

This field survey activity was carried out as an effort to identify Anopheles mosquito species in Betung Bedarah, Tebo Regency. Human landing collection method (catching mosquitoes by baiting people) at night 20.00-24.00 WIB and resting collection (catching mosquitoes directly while perching or resting) were methods used in sampling. Sampling was carried out randomly on 10-11 December 2017 in the Betung Bedarah of Anopheles mosquito species in Betung Bedarah, Tebo Regency, Jambi Province.

area, Jambi. Collection method used an aspirator (Figure 2) device and a light trap uses a light (light trap) and then is inserted into bufferglass.' Volunteer samples are used as bait during fishing.

Identification of Anopheles mosquito species using light microscope, magnification 10 and 40 objective lens, and confirmed according to Anopheles identification manual book ${ }^{9-11}$ by vector, disease control and eradication (pengendalian dan pemberantasan penyakit / P2P) officers.

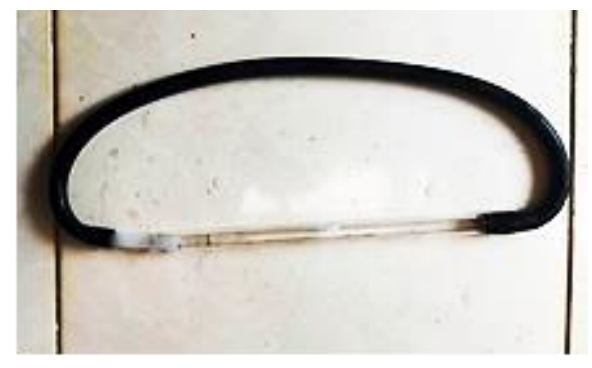

Figure 2. Aspirator ${ }^{6}$

\section{RESULTS}

Table 1. Types of mosquitoes in Betung Bedarah, Tebo Regency

\begin{tabular}{lccc}
\hline \multirow{2}{*}{ Types of mosquitoes } & \multicolumn{2}{c}{ Method of collection } & \multirow{2}{*}{ N (\%) } \\
\cline { 2 - 3 } & HLC $\mathbf{n}(\%)$ & RC $\mathbf{n}(\%)$ & \\
\hline Anophles & $12(18.7)$ & $4(6.3)$ & $16(25,0)$ \\
\hline Non Anopheles & $31(48.4)$ & $17(26.0)$ & $48(75.0)$ \\
\hline Total & $43(67.1)$ & $21(32.9)$ & $16(100.0)$ \\
\hline
\end{tabular}

$H L C=$ human landing colection, $R C=$ resting collection

Table 2. Anopheles mosquito species in Betung Bedarah, Tebo Regency

\begin{tabular}{lccc}
\hline \multirow{2}{*}{ Anopheles species } & \multicolumn{2}{c}{ Method of collection } & \multirow{2}{*}{ N (\%) } \\
\cline { 2 - 3 } & HLC n(\%) & RC n(\%) & \\
\hline Anopheles barbirostris & $5(41,6)$ & $2(50)$ & $7(43,7)$ \\
\hline Anopheles vagus & $3(25)$ & $1(25)$ & $4(25,0)$ \\
\hline Anopheles aconitus & $2(16,7)$ & $1(25)$ & $3(18,7)$ \\
\hline Anopheles kochi & $2(16,7)$ & $0(0)$ & $2(12,0)$ \\
\hline Total & $12(75)$ & $4(25)$ & $16(100)$ \\
\hline
\end{tabular}

$H L C=$ human landing colection, $R C=$ resting collection 
From table 1, of the 64 mosquitoes collected, 25\% were Anopheles (16 mosquitoes) and 75\% non Anopheles (48 mosquitoes) included Armigeres, Culex, and Mansonia. Most of mosquito species collected using human landing collection (HLC) method were 43 mosquitoes (67.1\%). Species analysis was only performed on Anopheles mosquitoes as a vector of malaria. Of the 16 Anopheles mosquitoes collected, 4 species were obtained consisting of 7 mosquitoes Anopheles barbirostris (43.7\%), 4 mosquitoes Anopheles vagus (25\%), 3 mosquitoes Anopheles aconitus (18.7\%), and 2 mosquitoes Anopheles kochi (12.6\%) (table 2).

\section{DISCUSSION}

From collection, a quarter of mosquitoes are Anopheles with spesies consisting of Anopheles barbirostris, Anopheles vagus, Anopheles aconitus, Anopheles kochi. Anopheles barbirostris and Anopheles aconitus were 2 of 15 Anopheles species that contributed to malaria in Sumatra. ${ }^{2}$ The largest Anopheles mosquito species found was Anopheles barbirostris. This result is similar to previous research in Teluk Kecimbung, Sarolangun Regency. ${ }^{6}$ Several studies in Jambi Provice had different results, in Nipah Panjang II Village, Tanjung Jabung Timur Regency was dominated by Anopheles letifer (40\%), in Muaro Jambi District was Anopheles Barbumbrosus, in Teluk Rumpang Village, Sarolangun Regency, ${ }^{8}$ and Nibung Putih Village, Muara Sabak Barat Subdistrict, Tanjung Jabung Timur Regency ${ }^{7}$ dominated by Anopheles nigerimus. Different results in other provinces such as in Lengkiti District, OKU, South Sumatra, showed that Anopheles mosquito species was dominated by Anopheles philippinensis, ${ }^{12}$ in Aceh Besar District dominated by Anopheles vagus, ${ }^{10}$ in South Lampung and Pesawaran Districts ${ }^{13}$ and Kenagarian Sungai Pinang Kecamatan Koto, West Sumatra ${ }^{14}$ dominated by Anopheles sundaicus. The difference Anopheles species population results may be due to differences in geographical description of each observation area.

Many Anopheles species prefer shade to support their breeding place. ${ }^{1}$ Anopheles breeding places include: rice fields, hills/ forests, and beaches/ rivers, ponds as well as kobakan/ place a puddle, ${ }^{8,14}$ lagoons, swamps, ponds. ${ }^{14}$ Environmental factors needed by larvae to support reproduction include $\mathrm{pH}$ and water vegetation as a source of survival. Breeding sites for Anopheles mosquitoes have a mean $\mathrm{pH}$ of 7.8 or breeding can be found in alkaline waters. Water vegetation is used by larvae to protect from sunlight, predators, and water surface movement. Water vegetation also makes it easier for Anophles larvae to get food. ${ }^{10}$ Humidity and rainfall have a significant effect on mosquito density, the higher humidity and rainfall, the higher mosquito density. ${ }^{13}$

Collected species of mosquitoes, is a category of mosquitoes that suck blood outside home (Anopheles barbirostris, Anopheles vagus, Anopheles kochi). Most of Anopheles vagus is zoophilic, exophagic and exophilic. Blood sucking activity Anopheles vagus on inside home occurs from 19.00 p.m. to 03.00 a.m., while peak activity outside home occurs at 18.00-19.00 p.m., in Anopheles barbirostris only happens outside home at 9.0022.00 p.m., and Anopheles kochi at 18.00-19.00 and 22.00-23.00 p.m. ${ }^{12}$

Anopheles mosquito can be identified by the same length of palpus as proboscis (in females) and the shape of the palpus is like a golf club (in males), black and white scaly patches on wings, perch angle of $50^{\circ}-90^{\circ}$ to surface. ${ }^{1,9}$ Identification key of Anopheles barbirostris includes on ribs and vein 1 there are 3 or less pale spots, palpi with pale rings, VII segment abdominal sternite with a brush consisting of dark scales, in middle of sternites from abdomen there are a collection of 8 (1) February 2021 
scales -white disk and there are usually two white stripes on sides consisting of white scales. ${ }^{10}$

\section{CONCLUSION}

Most of mosquito species collected at Betung Berdarah Tebo were Anopheles barbirostris. It is necessary to conduct geographic location analysis to describe breeding place of each species.

\section{REFERENCES}

1. Soedarto. Malaria, Referensi Mutakhir Epidemiologi Global-PalsmodiumAnopheles-Penatalaksanaan Penderita Malaria 2011. Jakarta: Sagung Seto. 2011

2. World Health Organization, Regional Office for South-East Asia. Anopheline Species Complexes in South and SouthEast Asia, SEARO Technical Publication No. 57. India: World Health Organization. 2007.

3. Jambi Provincial Health Office. Profil Kesehatan Provinsi Jambi 2017. Jambi: Dinkes Prov. Jambi. 2018.

4. Maloha MM, Ratnaningrum K. Sebaran Nyamuk Vektor di Betung Bedarah, Kabupaten Tebo, Provinsi Jambi. Medica arteriana, Vol 2, No 1 (2020): 21-26.

5. Supranelfy Y, Santoso. Sebaran Nyamuk Vektor di Kabupaten Muaro Jambi, Provinsi Jambi. Spirakel, Vol. 8 No 1, Juni Tahun 2016: 21-29.

6. Maloha MM. Identifikasi Nyamuk di Teluk Kecimbung, Kabupaten Sarolangun, Provinsi Jambi. Medica arteriana, Vol 1, No 2 (2019): 40-44.

7. Santosa, et al. Studi Bioekologi Nyamuk Mansonia spp Vektor Filariasis Di Kabupaten Tanjung Jabung Timur, Provinsi Jambi. Vektora, Vol 8 No 2, (2016): $71-80$.

8. Taviv Y, et al. Sebaran Nyamuk Anopheles pada Topografi Wilayah yang

Berbeda di Provinsi Jambi. Media Litbangkes, Vol. 25 No. 2, Juni 2015: 1-8.

9. Kementerian Kesehatan Republik Indonesia. Survei Vektor Malaria. Jakarta: Direktorat Jenderal Pencegahan dan Pengendalian Penyakit, Direktorat Pencegahan dan Pengendalian Penyakit Tular Vektor dan Zoonotik. 2018.

10. Yulidar. Survei nyamuk Anopheles yang diduga berpotensi sebagai vektor malaria di Kabupaten Aceh Besar. Jurnal Biologi Edukasi Edisi 19, Vol 9 No1, Juni 2017: 1-5.

11. Hidajati S, Dachlan YP, Yotopranoto S. Atlas Parasitologi Kedokteran. Jakarta: EGC. 2014.

12. Mahdalena V, Hapsari N, Nimah T. Keragaman Jenis Dan Aktivitas Mengisap Darah Anopheles Spp. Di Desa Simpang Empat Kecamatan Lengkiti Ogan Komering Ulu Sumatera Selatan. Aspirator, 8 (1), 2016: 9-16.

13. Suwito S. Distribusi spasial dan bioekologi Anopheles spp. di Lampung Selatan dan Pesawaran, Provinsi Lampung. Ejournal.litbang.depkes. Vol. 9, No.3, September 2010: 1290 -1302.

14. Lestari S, Adrial, Rasyid R. Identifikasi Nyamuk Anopheles Sebagai Vektor Malaria dari Survei Larva di Kenagarian Sungai Pinang Kecamatan Koto XI Tarusan Kabupaten Pesisir Selatan. Jurnal Kesehatan Andalas, 5(3), 2016: 656-660. 